\title{
93. Action of Mercaptanes on Bromotropolones and Their Methyl Ethers. Formation of Mercapto- tropolones and Their Rearrangement.
}

\author{
by Tetsuo Nozoz, Masatsune Satô, and Kazuo Matsui. \\ Chemical Institute, Faculty of Science, Tôhoku University, \\ Sendai, Japan. \\ (Comm. by R. MAJima, M.J.A., Oct. 13, 1952.)
}

As a part of studies on sulfur-containing troponoids ${ }^{1)}$, reaction of the sodium salts of methylmereaptane (I), thiophenol (II), and p-thiocresol (III) against the sodium salts $(\mathrm{A}: \mathrm{R}=\mathrm{Na}$ ) and methyl ethers $\left(\mathrm{A}: \mathrm{R}=\mathrm{CH}_{3}\right)^{3) \text { t) }}$ of tropolone (IV) ${ }^{2) 33}$, 3-bromotropolone (V), 3, 7-dibromotropolone (VI), and 3, 5, 7-tribromotropolone (VII) was carried out ${ }^{6)}$, and the general experimental results obtained to date are briefly described in the following. Very recently, Cook, and the others ${ }^{5)}$, also described the formation of 3 -p-tolylmercaptotropolone $(I X)$, m. p. $175^{\circ}$.

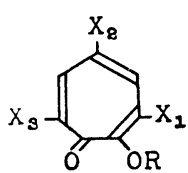

(A)

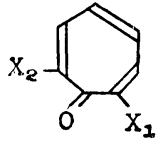

(B)

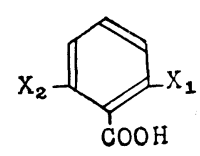

(c)

Tropolone (IV) and its Methyl Ether:

The sodium salt of tropolone was stable against sodium mercaptide (I, II, III), but its methyl ether yielded sodium tropolonate by the action of (III), and resulted in oily acid substance*) by the action of (I). 3-Bromotropolone $(V)$ and its Methyl Ethers ( $V a$ and $V b)$ :

The sodium salt of 3-bromotropolone, and the two methyl ethers derived from it, i.e. 7-bromotropolone methyl ether (Va) ${ }^{4) 7)}$, m. p. $90-91^{\circ}$, and 3-bromotropolone methyl ether $(\mathrm{Vb})^{7)}$, m. p. $76-77^{\circ}$, all yielded by the action of (II) 3-phenylmercaptotropolone (VIII, $\mathrm{A}: \mathrm{X}_{1}=$ $\mathrm{SC}_{6} \mathrm{H}_{5}, \mathrm{X}_{2}=\mathrm{X}_{3}=\mathrm{R}=\mathrm{H}$ ), as dark yellow seales, m.p. $140^{\circ}$ (Anal..$^{12)}$ Caled. for $\mathrm{C}_{13} \mathrm{H}_{10} \mathrm{O}_{2} \mathrm{~S}: \mathrm{C}, 67.79 ; \mathrm{H}, 4.38$. Found: $\left.\mathrm{C}, 67.35 ; \mathrm{H}, 4.65\right)$.

The sodium salt of $(\mathrm{V})$ yielded by the action of (III) 3-ptolylmercaptotropolone (IX, A: $\mathrm{X}_{1}=\mathrm{SC}_{7} \mathrm{H}_{7}, \mathrm{X}_{2}=\mathrm{X}_{3}=\mathrm{R}=\mathrm{H}$ ), as yellow prisms, m. p. $176^{\circ}$ (Anal. Caled. for $\mathrm{C}_{14} \mathrm{H}_{12} \mathrm{O}_{2} \mathrm{~S}:$ C, 68.82; H, 4.95. Found: C, 68.93; H, 4.90).

The liquid methyl ether, obtained by the action of diazomethane on (VIII), underwent rearrangement when heated with sodium methoxide in methanol giving an acid substance of colorless plates 
(X), m.p. $167^{\circ}$. This substance was identical with 2-phenylmercaptobenzoic acid $\left(\mathrm{C}: \mathrm{X}_{1}=\mathrm{SC}_{6} \mathrm{H}_{5}, \mathrm{X}_{2}=\mathrm{H}\right)$, m.p. $167^{\circ}$, in its melting point and crystal form as described in the literture ${ }^{8)}$, but the sample prepared by this method in this laboratory was colorless needles (XI), m.p. $167^{\circ}$, and the mixed fusion of (X) and (XI) gave approximately $30^{\circ}$ depression of the melting point. The sample of colorless plates, m.p, $167^{\circ}$, prepared from anthranilic acid and (II) according to the synthetic $\operatorname{method}^{9)}$ for 2-p-tolylmercaptobenzoic acid $\left(\mathrm{C}: \mathrm{X}_{1}=\mathrm{SC}_{7} \mathrm{H}_{7}, \mathrm{X}_{2}=\mathrm{H}\right)$, showed no depression of the melting point when fused with $(\mathrm{X})$ that it must be 2-phenylmercaptobenzoic acid.

On the application of 2 molar equivalents of (I), 7-bromotropolone methyl ether $(\mathrm{Va})$ yielded 2,7 -di(methylmercapto)tropone ${ }^{1)}\left(\mathrm{B}: \mathrm{X}_{1}=\right.$ $\mathrm{X}_{2}=\mathrm{SCH}_{3}$ ), as yellow prisms, m.p. 129-130 . The same treatment of 3-bromotropolone methyl ether ( $\mathrm{Vb}$ ) resulted in its facile rearrangement to 2-methylmereaptobenzoic acid ${ }^{10)}\left(\mathrm{C}: \mathrm{X}_{1}=\mathrm{SCH}_{3}, \mathrm{X}_{2}=\mathrm{H}\right)$, as colorless needles, m.p. $168^{\circ}$. Application of 1 molar equivalent of (I) to (Va) yielded a liquid whose hydrolysis with $5 \mathrm{~N}$ sodium hydroxide gave yellow prisms of m.p. $110^{\circ}$. Since this substance is also obtained by the hydrolysis of 2, 7-di (methylmercapto)tropone ${ }^{1)}$, its structure is assumed to be 3-methylmercaptotropolone ( $\mathrm{A}: \mathrm{X}_{1}=$ $\mathrm{SCH}_{3}, \mathrm{X}_{2}=\mathrm{X}_{3}=\mathrm{R}=\mathrm{H}$ ). Picrate: Red prisms, m.p. 101-102 ${ }^{\circ}$ (Anal. Calcd. for $\mathrm{C}_{14} \mathrm{H}_{11} \mathrm{O}_{9} \mathrm{~N}_{3} \mathrm{~S}$ : $\mathrm{N}, 10.58$. Found: $\left.\mathrm{N}, 10.47\right)$. Hydrochloride: Yellow crystals, m.p. $145-148^{\circ}$.

\section{3, 7-Dibromotropolone (VI) and its Methyl Ether (VIa):}

The sodium salt of (VI) failed to undergo any change when refluxed with (III) for 6 hours in ethanol, but yielded yellow prisms of m. p. $158-159^{\circ}$ (XII) when heated in sealed tube. (XII) shows brown coloration in the benzene layer with ferric chloride, and by the action of diazomethane, it gave pale yellow granular crystals (XIIa), m.p. $168^{\circ}$ (Anal. Caled. for $\mathrm{C}_{22} \mathrm{H}_{20} \mathrm{O}_{2} \mathrm{~S}_{2}$ : C, 69.44; H, 5.30. Found: C, 69.07; H, 5.73). (XIIa) was also obtained when (VIa) was refluxed with (III) for 6 hours in ethanol. It is noteworthy that (XIIa) shows considerable resistance to acid and alkali, but somewhat drastic treatment of (XIIa) with alcoholic alkali gave an acid substance (XIII), as colorless plates, m.p. 194º, which failed to give any coloration with ferric chloride (Anal. Calcd. for $\mathrm{C}_{21} \mathrm{H}_{18} \mathrm{O}_{2} \mathrm{~S}_{2}$ : $\mathrm{C}, 68.82 ; \mathrm{H}, 4.95$. Found: $\mathrm{C}, 68.71 ; \mathrm{H}, 4.99$ ). (XIII) failed to show any depression of the melting point when fused with 2, 6-di(ptolylmercapto) benzoic acid $\left(\mathrm{C}: \mathrm{X}_{1}=\mathrm{X}_{2}=\mathrm{SC}_{7} \mathrm{H}_{7}\right)$, colorless plates, m. $\mathrm{p}$. $192.5^{\circ}$, prepared for the first time from methyl 2, 6-dibromobenzoate and (III) by the method modified from that existing in literature ${ }^{11}$. Above-mentioned facts confirm that (XII) and (XIIa) is respectively, 
2, 7 -di(p-tolylmercapto)tropolone $\left(\mathrm{A}: \mathrm{X}_{1}=\mathrm{X}_{3}=\mathrm{SC}_{7} \mathrm{H}_{7}, \mathrm{X}_{2}=\mathrm{R}=\mathrm{H}\right)$ and its methyl ether $\left(\mathrm{A}: \mathrm{X}_{1}=\mathrm{X}_{3}=\mathrm{SC}_{7} \mathrm{H}_{7}, \mathrm{X}_{2}=\mathrm{H}, \mathrm{R}=\mathrm{CH}_{3}\right)$.

3, 5, r-Tribromotropolone (VII):

By refluxing (VII) with 4 molar equivalents of (III) in ethanol for 1-3 hours yielded monobromo-di(p-tolyimercapto)tropolone, as yellow needles, m.p. $216^{\circ}$ (Anal. Caled. for $\mathrm{C}_{21} \mathrm{H}_{17} \mathrm{O}_{2} \mathrm{~S}_{2} \mathrm{Br}$ : C, 56.63; $\mathrm{H}$, 3.85. Found: C, 56.27; H, 3.77), monobromo-di(p-tolylmercapto)tropolone, as yellow prisms, m. p. 155 ${ }^{\circ}$, (Anal. Found: C, 56.82; H, 3.54), and yellow needles (XIV), m.p. $165^{\circ}$ (Anal. Caled. for $\mathrm{C}_{11}$ $\mathrm{H}_{10} \mathrm{O}_{2} \mathrm{SBr}_{2}$ : C, 41.81; H, 2.50. Found: C, 41.62; H, 2.75). Since (XIV) is also obtained by the bromination of (IX) mentioned below, its structure is assumed to be 5, 7 -dibromo-3-p-tolylmercaptotropolone (XIV, A: $\mathrm{X}_{1}=\mathrm{SC}_{7} \mathrm{H}_{7}, \mathrm{X}_{2}=\mathrm{X}_{3}=\mathrm{Br}, \mathrm{R}=\mathrm{H}$ ).

Substitution Products of Mercaptoŕropolones:

Mercaptotropolones, as in the case of other tropolones, give sparingly soluble (in water) sodium salts, ferric and cupric complex salts, and generally undergo electrophilic substitutions. For example, bromination of (IX) gave (XIV), and its azo coupling with p-tolyldiazonium chloride yielded 5(?)-p-tolylazo-3-p-tolylmercaptotropolone, as red scales, m.p. $206^{\circ}$ (Anal. Calcd. for $\mathrm{C}_{21} \mathrm{H}_{19} \mathrm{O}_{2} \mathrm{~N}_{2} \mathrm{~S}: \mathrm{N}, 7.73$. Found: $\mathrm{N}, 7.70)$.

The detailed reports of the experiments herein described will be given in the near future. The present series of experiments were made possible by the donation of the Grant in Aid for Scientific Research from the Ministry of Education, and from the Asahi Newspapers, to whom the authors express their gratitude. Grateful acknowledgement is hereby expressed to Mr. M. Takahashi and Dr. F. Nagasawa of the Research Laboratory of the Mitsubishi Kasei K.K. for allowing one (Satô) of the authors to participate in the present work (at Sendai) and for the donation of some of the chemicals used.

\section{References.}

1) T. Nozoe, M. Satô, and K. Matsui : Proc. Japan Acad., 28, 407 (1952).

2) T. Nozoe, S. Seto, Y. Kitahara, M. Kunori, and Y. Nakayama: ibid., 26, 38 (1950).

3) J. W. Cook, A. R. Gibb, R. A. Raphael, and A. R. Sommerville: J. Chem. Soc., 1952, 503.

4) T. Nozoe, S. Seto, T. Ikemi, and T. Arai : Proc. Japan Acad., 27, 102 (1951).

5) B. D. Abadir, J. W. Cook, J. D. Loudon, and D. K. V. Steel : J. Chem. Soc., 1952, 2350.

*) Only once, a small amount of Carboxylic acid of m. p. 145-150 ${ }^{\circ}$ was obtained.

6) A part of this experiment was summarized in J. Chem. Soc. Japan, 73, (1952), in press.

7) T. Nozoe, Y. Kitahara, and S. Masamune: Proc. Japan Acad., 27, 649 (1951).

8) F. Mayer: Ber., 42, 1135 (1909).

9) F. Mayer : ibid., 43, 587 (1910).

10) O. Hinsberg: ibid., 43, 653 (1910).

11) J. Goldberg: ibid., 37, 4526 (1904).

12) Microanalyses were carried out by Messers. Hirai and Kawamoto of Sankyô, Co., Ltd., and K. Katô of this laboratory, the authors' gratitude hereby expressed. 